\title{
Mortality pattern in a glass producing area in SE Sweden
}

\author{
G WINGREN AND O AXELSON
}

From the Department of Occupational Medicine, Linköping University, S-581 85 Linköping, Sweden

ABSTRACT Because of discharges, mainly of lead, from glassworks in an otherwise rural and unpolluted area in southeast Sweden the population became concerned about the potential risks of cancer and an epidemiological study was requested. The total and the specific cancer mortality in the three parishes around the glassworks were found to be approximately normal, both by comparison with national death rates and the death rates of another, similarly rural, area. More interesting results, however, were obtained in several case-referent studies also undertaken to study mortality from specific cancer sites and cardiovascular disease with regard to employment in the glassworks. A significant excess of deaths from stomach cancer, especially in glassblowers, lung cancer, and cardiovascular disease was observed among the glassworkers. Occupational exposures in the glassworks, especially to arsenic, may be of aetiological importance.

The manufacturing of glass requires many potentially toxic agents including lead, cadmium, antimony, arsenic, copper, selenium, chromium, sulphuric acid, and hydrofluoric acid.' The use of arsenic in glass manufacturing has declined in recent years because of substitution with antimony, but asbestos has been used extensively in the glassworks until recently, especially in handling warm, newly made glass products. For example, in 1974 the consumption of asbestos is known to have amounted to seven tons for 27 Swedish glassworks taken together. ${ }^{2}$

Possible health hazards from the discharge of various metallic compounds from glassworks caused concern among the population in the glass producing area northwest of the town of Nybro in SE Sweden. The possibility of an increased risk from cancer to the general population was especially feared. The anxiety about adverse health effects had its origins in an environmental survey carried out by the health authorities of the county of Kalmar, indicating that about 10 tons of lead a year were discharged from one particular glassworks; this is thought to be one of the largest discharges of lead in Sweden (Kalmar and Nybro health authorities and Orrefors glassworks, unpublished data 1969-79).

In view of this concern, the local representatives of the Labour Union decided to call for an

Received 23 July 1984

Accepted 13 August 1984 epidemiological investigation of cancer mortality in the area. Finally, the matter was brought to our department and resulted in the present study.

Although the original purpose of this investigation was to study the general mortality pattern in three parishes northwest of Nybro, where the lead discharge had occurred, it was extended to consider the mortality pattern of the glassworkers. Therefore, several case-referent (case-control) evaluations were made for total cancer, cancers of the larynx and lung and of the stomach and pancreas, urogenital cancer, brain tumours, haematolymphatic malignancies, and also for cardiovascular diseases - that is, disorders that might be expected to appear in excess in view of the exposures at hand.

\section{Materials and methods}

The registers of deaths and burials in the parishes of Hälleberga, Madesjö, and Algutsboda were used as the source of subjects, all deceased, both for a general mortality study and for the case-referent studies relating to occupational exposures. The choice of subjects was restricted to men in cancer productive ages only - that is, 45 years or more-thereby also allowing somewhat for an induction-latency period. Based on the information in the registers, the causes of death were classified according to the 1965 International Classification of Disease (ICD) ${ }^{3}$

For the evaluation of the general mortality pattern in the area, the observed number of cases in the 
three parishes were compared with expected numbers calculated from the death rates for the whole of Sweden, ${ }^{4}$ but a comparison was also made to another, mainly rural parish in SE Sweden, Valdemarsvik.

The case-referent evaluations started from those cases in the three parishes who had died from any cancer (ICD 140-209), stomach cancer (ICD 151), pancreatic cancer (ICD 157), cancer of the larynx (ICD 161), lung cancer (ICD 162, 163), urogenital cancer (ICD 181-190), brain tumours (ICD 191), haematolymphatic malignancies (ICD 200-209), or from cardiovascular diseases (ICD 410-414 and 427-429). Referents were individuals in the same area who had died of other non-malignant and non-cardiovascular causes; they were selected according to principles delineated elsewhere. ${ }^{5}$ The exposure was taken as the registered title of occupation so that those who had been employed in the glassworks were regarded as exposed and those with other titles, such as farmer, joiner, or shopkeeper, were classified as unexposed. In about half the exposed subjects a separation into different work categories was possible according to the occupational titles. Hence, the following groups were created: $(a)$ glassblowers, $(b)$ other glass foundry workers including smelters, heaters, pressers, their assistants, and foundry foremen, (c) grinders, engravers, and cutters, $(d)$ etchers, polishers, and painters, $(e)$ controllers and packers, and $(f)$ unspecified glass workers.

\section{Statistical methods}

The calculations of odds ratios, (rate ratios, RR) and confidence intervals (CI) followed the principles of Mantel and Haenszel (MH) and Miettinen. ${ }^{7} 7$ The 95\% confidence intervals (CI 95) are given except when the $90 \%$ intervals (CI 90) tend to be more informative-that is, when the lower limit equals unity or is only slightly greater.

\section{Results}

On account of the limited access to national death rate statistics the mortality study covers only the years 1951-79. During this 29 year period 1677 men, aged 45 or more, died in the three parishes of Hälleberga, Madesjö, and Algutsboda. Table 1 gives the observed and expected numbers of deaths from all cancers, stomach cancer, and lung cancer. No excesses of deaths in any of these categories could be seen for the total population in the parishes, in the age groups studied. The result was the same when a comparison was made with the other rural parish.
The case-referent evaluations with regard to employment in glassworks covered 1950-82. An increase in total cancer mortality was seen to be associated with work in the glassworks, MH-RR = $1 \cdot 3$ and CI $90=1 \cdot 0-1 \cdot 7$. For stomach cancer (ICD 151), a significant and doubled risk was found with MH-RR $=2 \cdot 0$ and $\mathrm{CI} 95=1 \cdot 2-3 \cdot 5$. For lung cancer also there was a doubled risk with $\mathrm{MH}-\mathrm{RR}=2 \cdot 0$ and $\mathrm{CI} 90=1 \cdot 1-3 \cdot 7$ (table 2 ). For the other types of cancer the results were as follows: urogenital cancer (ICD 181-190) $\mathrm{MH}-\mathrm{RR}=1 \cdot 2,95$ cases; brain tumour (ICD 191) MH-RR $=1 \cdot 0,22$ cases; haematolymphatic malignancies (ICD 200-209) MH-RR $=0.64,21$ cases; pancreatic cancer (ICD 157) $\mathrm{MH}-\mathrm{RR}=0.57,27$ cases. No cases of laryngeal cancer (ICD 161) were found. In the evaluation of cardiovascular diseases (ICD 410-414 and 427-429) a significantly increased risk was found for glassworks employees, MH-RR $=1 \cdot 4, \mathrm{CI}$ $95=1 \cdot 1-1 \cdot 8$ (table 2$)$. A separation of the available occupational titles showed that the excess risk for stomach cancer was strongly related to the group of glassblowers $\mathrm{MH}-\mathrm{RR}=6 \cdot 4, \mathrm{CI} 95=3 \cdot 0-14 \cdot 0$. The excess risk for lung cancer occurred in the group of unspecified glassworkers $\mathrm{MH}-\mathrm{RR}=2 \cdot 4$, CI $95=$ $1.0-5.8$ and in the group of glass-controllers and packers $\mathrm{MH}-\mathrm{RR}=5 \cdot 6$, CI $95=1 \cdot 4-21 \cdot 5$. A relation to the groups of glassblowers and unspecified glassworkers was seen also for the excess in cardiovascular deaths, $\mathrm{MH}-\mathrm{RR}=1 \cdot 8, \mathrm{CI} 95=1 \cdot 0-3 \cdot 2$ and $\mathrm{MH}-\mathrm{RR}=1 \cdot 4, \mathrm{CI} 95=1 \cdot 0-2 \cdot 0$, respectively (table 3).

\section{Discussion}

The results of this study did not show an excess cancer mortality in the general population but rather the reverse, although only the older part of the male population was studied. The case-referent studies showed an interesting mortality pattern, however, with an increased risk for stomach cancer, lung cancer, and cardiovascular diseases for employees in the glassworks. The classification of exposure was somewhat crude, based as it was on occupational titles in the registers of deaths and burials; for only about half the subjects was a separation into different worker categories possible.

The expected number of cases for the whole study period may be calculated from the figures given in table 2 and is 10.7 for stomach cancer, 4.4 for lung cancer, and 111.1 for cardiovascular diseases. Thus the formal numbers of excess deaths are $13 \cdot 3,6 \cdot 6$, and 48.2 cases, respectively, in 33 years. These figures might be compared with the 1881 deaths included in the study, of which $17.9 \%$ or 337 deaths would have been expected among the glassworkers 
Table 1 Mortality pattern among men aged 45 or more in three parishes in the glassworks district in SE Sweden for 1951-79. Expected number of cases are calculated from the death rates of the whole nation

\begin{tabular}{|c|c|c|c|c|c|c|c|c|c|c|c|c|}
\hline \multirow[b]{2}{*}{ Age } & \multicolumn{3}{|c|}{ Total mortality } & \multicolumn{3}{|c|}{ Total cancer mortality } & \multicolumn{3}{|c|}{ Stomach cancer mortality } & \multicolumn{3}{|c|}{ Lung cancer mortality } \\
\hline & $\begin{array}{l}\text { Observed } \\
\text { (O) }\end{array}$ & $\begin{array}{l}\text { Expected } \\
(E)\end{array}$ & $O / E$ & $\begin{array}{l}\text { Observed } \\
\text { (O) }\end{array}$ & $\begin{array}{l}\text { Expected } \\
(E)\end{array}$ & $O / E$ & $\begin{array}{l}\text { Observed } \\
\text { (O) }\end{array}$ & $\begin{array}{l}\text { Expected } \\
(E)\end{array}$ & $O / E$ & $\begin{array}{l}\text { Observed } \\
\text { (O) }\end{array}$ & $\begin{array}{l}\text { Expected } \\
(E)\end{array}$ & $O / E$ \\
\hline $\begin{array}{l}45-64 \\
65-74 \\
\geqslant 75 \\
\geqslant 45\end{array}$ & $\begin{array}{r}287 \\
441 \\
949 \\
1677\end{array}$ & $\begin{array}{r}352 \cdot 3 \\
628 \cdot 1 \\
995 \cdot 8 \\
1712 \cdot 6\end{array}$ & $\begin{array}{l}0.8 \\
0.7 \\
1.0 \\
1.0\end{array}$ & $\begin{array}{r}73 \\
110 \\
142 \\
325\end{array}$ & $\begin{array}{r}88.6 \\
151.0 \\
164.1 \\
354.3\end{array}$ & $\begin{array}{l}0.8 \\
0.7 \\
0.9 \\
0.9\end{array}$ & $\begin{array}{l}12 \\
28 \\
24 \\
64\end{array}$ & $\begin{array}{l}13 \cdot 6 \\
25 \cdot 2 \\
28 \cdot 4 \\
58 \cdot 8\end{array}$ & $\begin{array}{l}0.9 \\
1 \cdot 1 \\
0.8 \\
1 \cdot 1\end{array}$ & $\begin{array}{r}6 \\
12 \\
6 \\
24\end{array}$ & $\begin{array}{l}15 \cdot 8 \\
23 \cdot 7 \\
14 \cdot 1 \\
48 \cdot 4\end{array}$ & $\begin{array}{l}0.4 \\
0.5 \\
0.4 \\
0.5\end{array}$ \\
\hline
\end{tabular}

Table 2 Case-referent data encompassing men aged 45 or more in three parishes in the glassworks district in SE Sweden for 1950-82. Referents are subjects dying from non-cancer and non-cardiovascular disorders. Exposure is taken as glassworks employment

\begin{tabular}{|c|c|c|c|c|c|}
\hline \multicolumn{2}{|l|}{ Age } & \multirow{2}{*}{$\begin{array}{l}\begin{array}{l}\text { Stomach cancer } \\
(\text { ICD 151) }\end{array} \\
7 \\
5\end{array}$} & \multirow{2}{*}{$\begin{array}{l}\text { Lung cancer } \\
\text { (ICD 162, 163) } \\
\begin{array}{l}4 \\
4\end{array}\end{array}$} & \multirow{2}{*}{$\begin{array}{l}\text { Cardiovascular deaths } \\
\text { (ICD 410-414 and } \\
427-429) \\
28 \\
67\end{array}$} & \multirow{2}{*}{$\begin{array}{l}\text { Referents } \\
\\
42 \\
97\end{array}$} \\
\hline $45-64$ & $\begin{array}{l}\text { Exposed } \\
\text { Unexposed }\end{array}$ & & & & \\
\hline $65-74$ & $\begin{array}{l}\text { Exposed } \\
\text { Unexposed }\end{array}$ & $\begin{array}{l}11 \\
22\end{array}$ & $\begin{array}{r}4 \\
12\end{array}$ & $\begin{array}{r}57 \\
123\end{array}$ & $\begin{array}{r}39 \\
140\end{array}$ \\
\hline$\geqslant 75$ & $\begin{array}{l}\text { Exposed } \\
\text { Unexposed }\end{array}$ & $\begin{array}{r}6 \\
22\end{array}$ & $\begin{array}{l}3 \\
4\end{array}$ & $\begin{array}{r}75 \\
320\end{array}$ & $\begin{array}{r}68 \\
447\end{array}$ \\
\hline Total & $\begin{array}{l}\text { Exposed } \\
\text { Unexposed }\end{array}$ & $\begin{array}{l}24 \\
49\end{array}$ & $\begin{array}{l}11 \\
20\end{array}$ & $\begin{array}{l}160 \\
510\end{array}$ & $\begin{array}{l}149 \\
684\end{array}$ \\
\hline \multicolumn{2}{|c|}{$\begin{array}{l}\text { Crude rate ratio } \\
\text { SMR } \\
\text { Mantel-Haenszel chi square } \\
\text { Mantel-Haenszel rate ratio } \\
\text { With } 95 \% \text { confidence interval }\end{array}$} & $\begin{array}{l}2 \cdot 2 \\
2 \cdot 1 \\
6 \cdot 8 \\
2 \cdot 0 \\
(1 \cdot 2-3 \cdot 5)\end{array}$ & $\begin{array}{l}2 \cdot 5 \\
1 \cdot 9 \\
3 \cdot 2 \\
2 \cdot 0 \\
(1 \cdot 1-3 \cdot 7)^{*}\end{array}$ & $\begin{array}{l}1 \cdot 4 \\
1 \cdot 4 \\
7 \cdot 7 \\
1 \cdot 4 \\
(1 \cdot 1-1 \cdot 8)\end{array}$ & $\begin{array}{l}(1 \cdot 0) \\
(1 \cdot 0) \\
(1 \cdot 0) \\
(1 \cdot 0)\end{array}$ \\
\hline
\end{tabular}

${ }^{*}$ Value is given with $90 \%$ confidence interval.

Table 3 Distribution of cases and referents in different work categories. Material encompasses men aged 45 or more who died during 1950-82. Referents are subjects dying from non-cancer and non-cardiovascular disorders. The age stratification underlying the analyses is omitted

\begin{tabular}{|c|c|c|c|c|c|c|c|c|c|c|}
\hline Work categories & Referents & \multicolumn{2}{|c|}{$\begin{array}{l}\text { Stomach cancer } \\
\text { (ICD 151) }\end{array}$} & CI 95 & \multicolumn{2}{|c|}{$\begin{array}{l}\text { Lung cancer } \\
\text { (ICD } 162,163)\end{array}$} & CI 95 & \multicolumn{3}{|c|}{$\begin{array}{l}\text { Cardiovascular deaths } \\
\text { (ICD 410-414 and 427-429) } \\
\text { Cases RR CI } 95\end{array}$} \\
\hline $\begin{array}{l}\text { Unexposed } \\
\text { A Glassblowers } \\
\text { B Other foundry workers } \\
\text { C Grinders, engravers, } \\
\text { and cutters }\end{array}$ & $\begin{array}{r}684 \\
19 \\
6 \\
32\end{array}$ & $\begin{array}{r}49 \\
8 \\
1 \\
5\end{array}$ & $\begin{array}{l}6 \cdot 4 \\
1 \cdot 7 \\
2 \cdot 0\end{array}$ & $\begin{array}{l}3 \cdot 0-14 \cdot 0 \\
0 \cdot 23-12 \cdot 9 \\
0 \cdot 71-5 \cdot 8\end{array}$ & $\begin{array}{r}20 \\
0 \\
0 \\
2\end{array}$ & $\overline{\overline{1}}$ & $\overline{\overline{0}}$ & $\begin{array}{r}510 \\
25 \\
8 \\
27\end{array}$ & $\begin{array}{l}1 \cdot 8 \\
1 \cdot 7 \\
1 \cdot 1\end{array}$ & $\begin{array}{l}1.0-3 \cdot 2 \\
0.59-4.9 \\
0.64-1.9\end{array}$ \\
\hline $\begin{array}{l}\text { D Etchers, polishers, } \\
\text { and painters }\end{array}$ & 7 & 0 & - & - & 0 & - & - & 9 & $1 \cdot 7$ & $0.63-4.5$ \\
\hline $\begin{array}{l}\text { E Controllers and packers } \\
\text { F Glassworkers (not specified) }\end{array}$ & $\begin{array}{r}9 \\
76\end{array}$ & $\begin{array}{l}1 \\
9\end{array}$ & $\begin{array}{l}1 \cdot 2 \\
1 \cdot 5\end{array}$ & $\begin{array}{l}0.14-11 \cdot 4 \\
0.68-3 \cdot 2\end{array}$ & 2 & $\begin{array}{l}5 \cdot 6 \\
2 \cdot 4\end{array}$ & $\begin{array}{l}1 \cdot 4-21 \cdot 5 \\
1 \cdot 0-5 \cdot 8\end{array}$ & $\begin{array}{r}9 \\
82\end{array}$ & $\begin{array}{l}1 \cdot 3 \\
1 \cdot 4\end{array}$ & $\begin{array}{l}0.54-3 \cdot 4 \\
1 \cdot 0-2 \cdot 0\end{array}$ \\
\hline
\end{tabular}

according to the proportion of exposed referents in table 2; the excess included and disregarded competing causes of deaths. In view of these figures it is understandable why there was no general increase in mortality in rural parishes which tend to have a low cancer mortality.

No association between the increased cause specific mortalities and any specific factor can be claimed at the present but the use of arsenic in glass production deserves special attention. It may be recalled in this context that stomach cancer, lung cancer, and to some extent other malignancies have appeared in excess among copper smelters who were exposed to arsenic and to a multitude of other metals as well; their exposure was somewhat similar to that of the workers in the present study. ${ }^{89}$

High concentrations of dust containing heavy metals and arsenic may occur in a glass foundry, especially when the glass batch is mixed, put in the furnace, and melted. Dry sweeping of the floors has been common and increases the dust exposure. ${ }^{2}$ Data supporting the occurrence of extreme expos- 
ures for the foundry workers have also been reported in a German study, where rather high blood lead concentrations were found especially among glass smelters, batch mixers, and furnace men, ${ }^{10}$ but there is little support for cancer or cardiovascular effects from lead exposure. ${ }^{112}$ The highly increased risk for stomach cancer just among the glassblowers is an interesting finding because of their unique exposure through direct oral contact with the pipe used for blowing the glass.

The background of the increased risk of lung cancer is difficult to evaluate since most cases were found in the group without specified work tasks. Nevertheless, the work environment, at least in earlier years, would have resulted in exposure to both arsenic and asbestos, both recognised respiratory carcinogens. There may also have been more smokers in the unskilled group of unspecified workers. The same may apply to the controllers and packers.

The possible relation between arsenic exposure and cardiovascular diseases, which was also apparent in two earlier studies ${ }^{913}$ is of interest in this context. Interestingly, the present study shows an increased risk for cardiovascular mortality only for the two categories with high risks of cancer, the glassblowers and the unspecified glassworkers.

The results of this preliminary study are of interest also because they indicate the possibility of obtaining another group of workers for study with regard to metal exposures, particularly to arsenic and lead, and they provide another indication that stomach cancer should sometimes be regarded as of occupational origin. The possible relation between exposure to arsenic and cardiovascular diseases especially needs to be studied further to confirm or refute the results reported so far.

\section{References}

' Swedish National Environmental Protection Board. Glasbrukens miljöproblem, Stockholm: 1978. (PM 1023.)

${ }^{2}$ Union of the Swedish Factory Labours and the Employers Confederation of the Glass Industry. Glasindustrins Arbetsmiljö, Stockholm: 1978.

${ }^{3}$ National Board of Health and Welfare. International statistical classification of diseases, injuries and causes of death. (1965 revision adapted for indexing of hospital records and morbidity statistics) Stockholm: Socialstyrelsen, 1973.

${ }^{4}$ National Central Bureau of Statistics. Causes of death 19511979 and census of the population 1965, 1970 and 1975. Stockholm: Statistiska Centralbyrån, the respective years.

${ }^{5}$ Axelson O, Flodin U, Hardell L. A comment on the reference series with regard to multiple exposure evaluations in a casereferent study. Scand J Work Environ Health 1982;8, suppl 1:15-9.

- Mantel M, Haenszel W. Statistical aspects of the analysis of data from retrospective studies of disease. J Natl Cancer Inst 1959;23:719-48.

' Miettinen OS. Standardization of risk ratios. Am J Epidemiol 1972;96:383-8.

${ }^{8}$ Wall S. Survival and mortality pattern among Swedish smelter workers. Int J Epidemiol 1980;9:73-87.

'Axelson O, Dahlgren E, Jansson C-D, Rehnlund SO. Arsenic exposure and mortality: a case-referent study from a Swedish copper smelter. $\mathrm{Br} J$ Ind Med 1978;35:8-15.

${ }^{10}$ Schaller von KH, Welte D, Schiele R, Weissflog S, Mayer P, Valentin H. Pilotstudie zur Quantifizirung der Bleieinwirkung in der keramische und Glas-Industrie. Zentralblatt für Arbeitsmedizin, Arbeitsschütz, Prophylax und Ergonomie 1981;31:442-52.

" Hernberg S. Lead. In: Zenz C, ed. Occupational medicine. Principles and practical applications. Chicago: Yearbook Medical Publishers, 1975:715-69.

${ }^{12}$ Fine L. Occupational heart disease. In: Rom WN, ed. Environmental and occupational medicine. Boston: Little, Brown and Company, 1983:359-65.

${ }^{13}$ Lee AM, Fraumeni JF. Arsenic and respiratory cancer in men, an occupational study. J Natl Cancer Inst 1969;42:1045-52. 